\title{
The Implementation and Evaluation of an Instructional Design Based on the Interdisciplinary Approach: Conscious Consumer Education
}

\author{
Memet Karakuş ${ }^{1}$ \& Melis Yeşilpınar Uyar $^{2}$ \\ ${ }^{1}$ Educational Sciences, Çukurova University, Adana, Turkey \\ ${ }^{2}$ Educational Sciences, Dumlupınar University, Kütahya, Turkey \\ Correspondence: Melis Yeşilpınar Uyar, Faculty of Education, Dumlupınar University, Kütahya, TR-43290, \\ Turkey. E-mail: myesilpinaruyar@gmail.com
}

\author{
Received: November 3, 2017 Accepted: November 30, $2017 \quad$ Online Published: December 21, 2017 \\ doi:10.5539/jel.v7n2p65 URL: http://doi.org/10.5539/jel.v7n2p65
}

\begin{abstract}
The aim of this study was to implement and evaluate the instructional design prepared as consumer-oriented and based upon interdisciplinary curriculum. In this study, case study approach, which is one of the qualitative research patterns, was employed. Observations, interviews and document analysis were used to collect data. For analyzing the data, inductive and deductive content analysis methods in the scope of the content analysis were used in combination. Consequently, it was indicated that instructional design which was developed with an interdisciplinary approach contributed to gain interdisciplinary knowledge and skills and develop consumer consciousness. In the light of these results we may conclude that this design is implementable. However, it was clear that the students had difficulties in points such as performing mathematical operations and expressing warrants. These situations made the implementation process more difficult. These results will contribute to the development of various approaches in mathematics instruction and the diversification of the implementations regarding mathematics use in real life.
\end{abstract}

Keywords: conscious consumer education, instructional design, interdisciplinary approach, mathematics instruction

\section{Introduction}

The rapid increase of knowledge requires this knowledge to be critically questioned, evaluated and used in various educational settings. This situation brings about analysis, evaluation and development of alternative approaches effective in students' gaining various knowledge and skills. Educators aim to gain students skills and topics related to real life with a thematic approach through the stated studies (Armstrong, 2000). Therefore, curricula require interdisciplinary implementations; consequently a transformation towards these has gained momentum (Armstrong, 2000; Campbell \& Henning, 2010; Jones, 2009; Lattuca, Voigt, \& Fath, 2004 cited in Mansilla \& Duraising, 2007; Lonning, DeFranco, \& Weinland, 1998; Ulusoy, 2007; Wagner, Murphy, Holderegger \& Waits, 2012).

Interdisciplinary, thematic and integrated concepts are related and are used interchangedly in the literature (Loepp, 1999; Lonning et al., 1998). Jacobs (1989, s. 8), for example referring to interdisciplinarity, defines this approach as a viewpoint of a knowledge implementing the method and language based on more than one discipline in order to analyze a theme, topic, problem or experience in the center. Integration, on the other hand, helps to describe the nature of the relationship between two or more disciplines within interdisciplinary units (Lonning et al., 1998). While the students' solving real life problems and making implementations in new situations through an interdisciplinary approach is emphasized (Loepp, 1999; Kander, 2003; Mallanda, 2011), it is stated that it is necessary to take a student-centered approach as a basis in classes when the interdisciplinary approach is used (Mallanda, 2011). In this sense, it is asserted that an interdisciplinary approach gives students a chance to see different viewpoints, work in groups and make a synthesis to reach the aim of disciplines (Jones, 2009).

The need for an interdisciplinary approach is explained with the tendency of individuals for perceiving their environment in a holistic way (Lucas, 1981), the emergence of new study fields based on the knowledge and skills of more than one discipline as a result of developing and accumulating wide knowledge (Yıldırım, 1996). 
The findings of the recent studies also show that implementations based on an interdisciplinary approach increase academic achievement (Bristow, 2012; Caplinger, 2013; Faulkner, 2012; Dean, 2014; Joseph, 2013; Mallanda, 2011; Martin, 2011; Miller, 2011; Nickson, 2014; Peterson, 2012; Ürey, 2013; Wei, 2012), active involvement (Giglio, 2012) and motivation of students (Guthrie, Wigfield, \& VonSecker, 2000; Kelly, 2011), and can contribute to skills and knowledge regarding various fields and development of higher order thinking skills (Campbell \& Henning, 2010; Caplinger, 2013; Faulkner, 2012; Lynch, 2013; Pierce, 2013; Tuncel \& Demirel, 2010; Yıldız \& Bümen, 2013).

Another dimension of the need for interdisciplinary implementations is related to its role in solving social problems. It is indicated that it is so difficult to find a solution with the viewpoint of one discipline for the complicated structure of socioeconomical and political problems encountered when taken into consideration through social context (Brown, 2006; Lomofsky \& Lazarus, 2001; Ulusoy, 2007). One of the problems can be dealt within this scope and requires gaining knowledge and skills related to various fields is consumer education. The rapid increase of consumption based on increasing produce is considered as an indicator of the consumer habits' change. In this regard, it is stressed that global warming, energy depression, famine and increase of prices, product and service variety, advertisements and income level of consumer are among the factors causing this change (Hayta, 2009). These matters addressed at global level bring the need for consumer education to the front While consumer education is thought to be a process directing individuals' economic activities, including increasing consumer awareness regarding the conscious use of sources as a fundamental right. This process involves curricula and tools prepared for making every individual in the society a conscious consumer and citizen (Altıok \& Babaoğul, 2010).

In this sense, consumer education is related to subject fields such as environment education (Bener \& Babaoğul, 2008, Hayta, 2009; Tanrıverdi, 2009), universal consumer rights (Babaoğul \& Altık, 2007) and it is indicated that the effect of social and economic factors (Çınar \& Çubukçu, 2009; Hekimci, 2010; Öktem \& Seçkiner, 2010), communication technologies (Büyükkantarcioğlu, 2007; Pektaş, 2007; Şener, 2010) and visual elements (Güzeloğlu, 2010) on consumer choices through this process should be taken into consideration. This shows that consumer education must address knowledge and skills from the social sciences, mathematics, media literacy, visual arts and science, making real life association with mathematics courses as well.

Our literature review was focused on the integration of fields such as mathematics, science, technology, arts, English, music with a particular emphasis on achievement and motivation (Caplinger, 2013; Dean, 2014; Joseph, 2013; Kelly, 2011; Nickson, 2014; Ürey, 2013; Wei, 2012). Within interdisciplinary implementations there is a limited number of study analyzing the learning-teaching process, students and teachers' perceptions and experiences through this process draw the attention (Bazemore, 2015; Brown, 2012; Doğan, 2014; Giglio, 2012; MacMath, 2011; Thompson, 2015). In this regard, it is indicated that there is an important lack regarding fundamental indicators concerning the quality of interdisciplinary implementations (Mansilla \& Duraising, 2007).

In the light of these points, there is a need for implementing an instructional design taking interdisciplinary approach as basis for developing consumer consciousness and analyzing the contributions and limitations of this implementation process. Considering this need, this study was aimed to implement and evaluate the instructional design called "Conscious Consumer Education" centering on the concept of consumption and based on interdisciplinary approach.Through this aim, this study was aimed at answering the following research questions:

- How is the function of instructional design in implementation?

- What are the contributions of implementation process to students?

- What are difficulties experienced in the implementation process?

- What are students' suggestions regarding the development of the implementation process?

\section{Method}

\subsection{Research Design}

In the study, case study one of the qualitative research designs was used. A case study analyses a determined setting or topic in depth and in a multidimensional way (Merriam, 1988; Patton, 2002; Stake, 1995). In order to examine the instructional design in depth, a single unit of analysis was explored in a holistic way; therefore holistic single case study design was used. Holistic single case design is aimed at looking at a single analysis unit within one specific context (Yin, 2003). 


\subsection{Case: Function of Instructional Design in Implementation}

The case described in this study was function of instructional design in implementation. The instructional design implemented in this study prepared by Karakuş and Yeşilpınar (2013) centered on consumption. Based on interdisciplinary design principles (Burton, 2001; Drake, 2007; Jacobs 1989), we identified the subject fields that had meaningful and distinct links related to consumption. Considering the links between subject fields, the goals, learning outcomes, skills and generalizations were put forward. The goals of the instructional design were increasing students' awareness of the elements leading their consumer behaviours and habits, their questioning these elements from a critical viewpoint, using their various knowledge and skills effectively through a life-oriented decision-making process and in the process gaining a conscious consumer point of view sensitive to environmental and social issues. The reach 21 learning outcomes written in line with these goals, lesson plans linking concepts drawn from mathematics, social sciences, science, visual arts and media literacy were developed and implemented. During the implementation process, worksheets, summative and formative assessment were used. In this context, assessment sheets prepared to be implemented by the end of each activity and a project assignment given at the end of implementation were used.

In this context, implementations of teacher and performance indicators of students have carried out in the learning-teaching processes of instructional design have formed the units of analysis in the research. Through these implementations, the contribution of this process to students learning, the difficulties that students have faced in the process, their suggestions they have made to improve the process were determined. In the light of these findings, the function of instructional design and fundamental indicators of interdisciplinary implementations were determined and evaluated.

\subsection{Participants}

Thirty students at a sixth grade of a state school and attending in mathematics practices course participated in this sample chosen through convenience sampling (Patton, 2002). Besides one of the researchers preparing and implementation the instructional design were the participants of the study. At the end of implementation process, semi-structured interviews with seven volunteers were conducted based on a criterion-based sampling method. The criteria for choosing the participants were their participation in the whole process and being at different levels of academic success in the mathematics course. Two of the interviewed students were female while the other five were male. The mathematics course grades of participants during previous semester ranged between three and five.

\subsection{Instrument}

As data collection, observation, interviews and document analysis were used. To prepare for the interview and evaluation form expert opinion was sought. Based on the feedback by the experts, necessary corrections were made and the forms were re-designed. The interview form consisted of questions on students views of the teaching process and assessment tools used in the course. Furthermore, the evaluation form students filled in at the end of every implementation were analyzed.

In the evaluation form, students were asked what kind of knowledge related to which courses other than mathematics they were given at the evaluation time, which real life knowledge and skills were gained by the end of the course, what the topics and activities drew their attention most throughout the process and what differences to other courses they could identify.

\subsection{Data Collection and Analysis}

As first step of data collection process, we observed the implementation of the instructional design over a period of eight weeks with 16 hours of lessons. During this process, the lessons were video recorded and it was provided that students filled in the evaluation forms at certain intervals. Through this process unstructured observation type (Yıldırım \& Şimşek, 2008) was used. After the observation phase semi-structured interviews were conducted with seven sixth grade students. For data analysis, we used both deductive analysis and inductive analysis (Patton, 2002). For deductive analysis method the literature regarding interdisciplinary teaching was reviewed (Meeth, 1978, cited in Garkovich, 1982; Jacobs, 1989; Erickson, 1995; Yıldırım, 1996; Martinello, 2000; Özkök, 2005; Mansilla \& Duraisingh, 2007; Campbell \& Henning, 2010) and categories were formed. Analysis of the data revealed further categories.

Strategies recommended in terms of validity and reliability studies (Bogdan \& Biklen, 2007; Brantlinger, Jimenez, Klingner, Pugach, \& Richardson, 2005; Creswell, 2008; Guba, 1981; Johnson \& Chiristensen, 2004; Patton, 2002; Shenton, 2004; Yıldırım \& Şimşek, 2008) were considered. In this context, in depth data was collected and observations (16 lesson hours) were made existing in study setting for a long time (March, 2014- 
May, 2014). Data was triangulated using a variety of data collection methods such as observation, interview and document analysis. The findings obtained were sent for expert opinion and confirmation. Evaluation meetings were held with a researcher and an expert conducting qualitative studies in curriculum and instruction field. During these meetings, the data gathered was presented to the experts, the raw data texts were analyzed for to match with the categories from the literature review and consistency between research design, findings and results was evaluated. The findings obtained were described and supported by quotations. In the direct quotations, the method through which data was gathered and the date were indicated for the students interviewed codes such as S1, S2 were used and the students outside the interviews were labeled by the capital letters of their names. By recording the interviews with a tape recorder and the observations with video camera data loss was prevented.

\section{Results}

\subsection{Function of Instructional Design in Implementation}

Categories emerging from the data -obtained from observations- that explain the function of instructional design were, "teachers' behaviors and implementations" and "performance indicators of students".

\subsubsection{Teachers' Behaviors and Implementations}

The categories and sub-categories regarding the teachers' behaviors and implementations were presented on Figure 1.

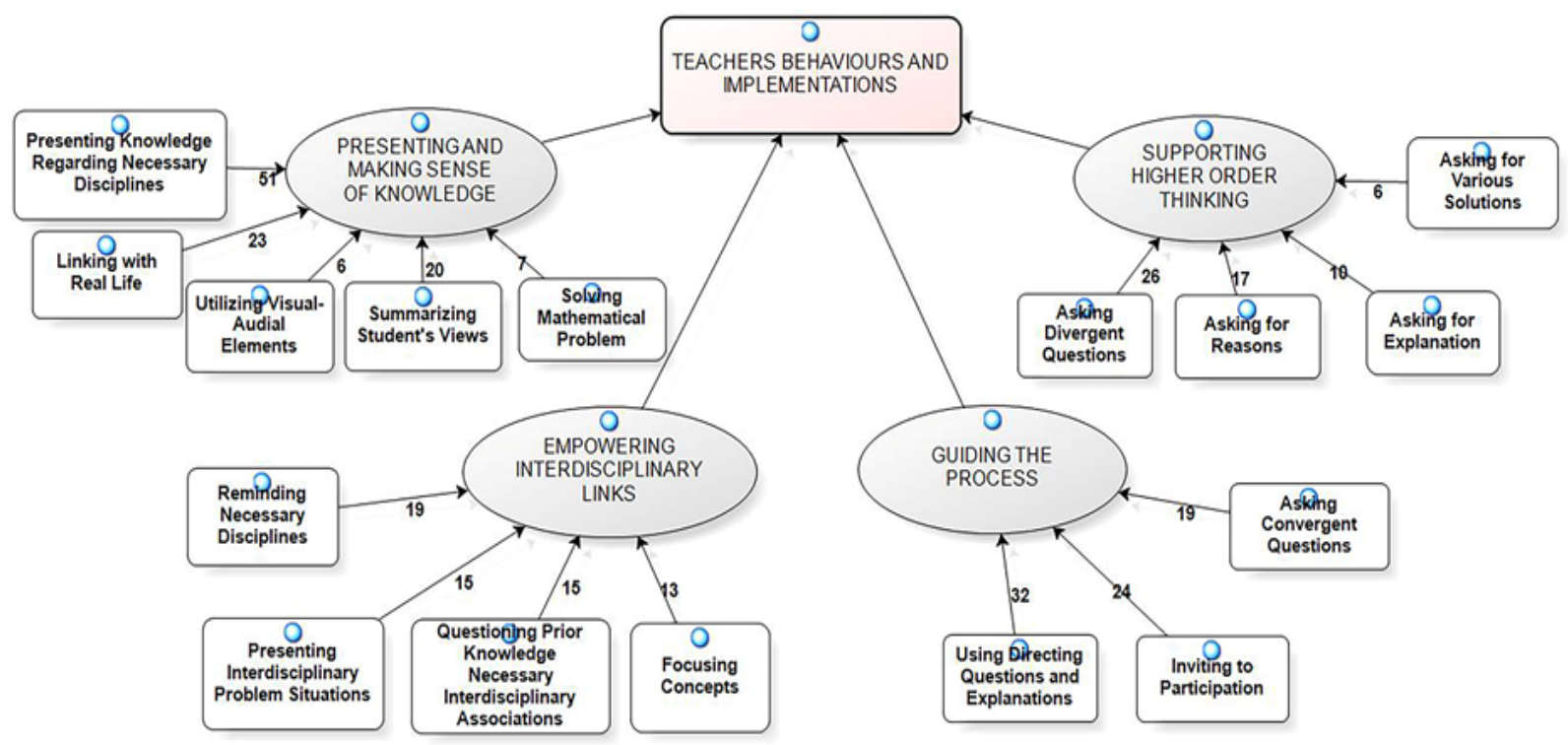

Figure 1. Teachers' behaviors and implementations

As seen on Figure 1, it was indicated that under the presenting and making sense of knowledge category implementer-researcher presented knowledge regarding necessary disciplines, linked with real-life, summarized the student views, utilized visual and audial elements and included the mathematical problem solving activities. The expression of implementer-researcher including the statement of knowledge presentation regarding necessary disciplines was as:

I guess the cost of water changes up to family. But we calculate for the water we use. In addition to this, what we pay in common? Maintenance cost, value-added tax, environment tax, pre-fractions these are all the things we pay in common (Observation, March 13, 2014).

Under the reinforcement of interdisciplinary links category, it was observed that she reminded necessary disciplines, questioned the prior knowledge necessary for these interdisciplinary associations, presented interdisciplinary problem situations and focused on concepts. This was expressed in the following statement related to linking to other disciplines and questioning prior knowledge as: 
Through the short text we write for defining our view, you write compositions in Turkish lesson, aren't you? I want you to consider whatever rules you care for writing those compositions, also take into consideration in this short text. What are these rules? (Observation, March 20, 2014).

On the other hand, related to supporting a higher order thinking category, it was indicated that divergent questions were asked; reason, explanation and different solution ways were demanded. One of the questions researcher-implementer asked in a divergent type was as for example:

Which one is the most suitable gold economic family could buy for their cousins up to you? (Observation, May 22, 2014).

Furthermore, it was observed that she guided the process using leading questions and explanations, inviting students to participate in the class and asking convergent questions to them. The implementer-researcher encouraged students to participate for example with:

Let's hear other problems....Yes, what are the other problems? I want to see your fingers today (Observation, April 10, 2014).

\subsubsection{Performance Indicators of Students}

The categories and sub-categories regarding the performance indicators of students were presented on Figure 2.

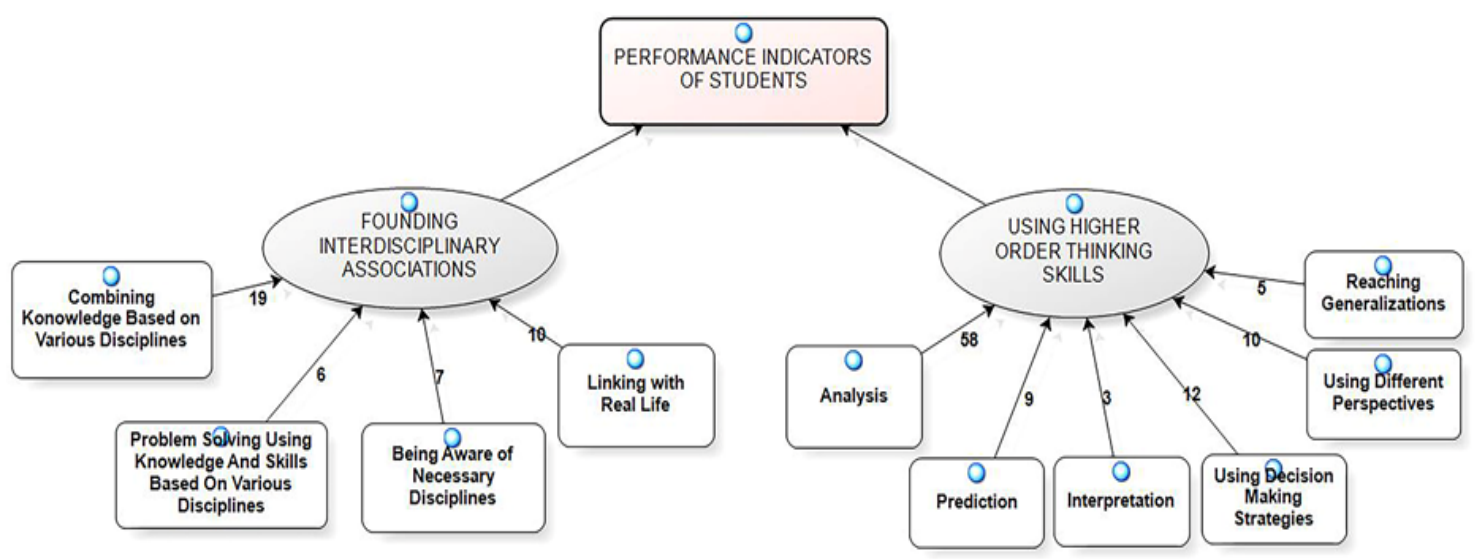

Figure 2. Performance indicators of students

Analyzing Figure 2, it was seen that they used higher order thinking skills such as analysis, prediction and interpretation, using decision making strategies and various viewpoints and reaching generalizations. It was found that students stated the problems they encountered analyzing presented case as:

Teacher, there they see the yoghurt with buy one get one they buy without any necessity (Observation, May 15, 2014).

There spend so much money, there won't remain any money. They spend unnecessarily according to their wishes... (Observation, May 22, 2014).

When they buy one yoghurt as it is at half-price it is rotten.... (Observation, May 22, 2014).

Their losing the warranty certificate of iron.... (Observation, May 22, 2014).

Related to the founding interdisciplinary associations category, we found that students combined knowledge based on various disciplines; they solved problems using these knowledge and skills; they were aware of necessary disciplines and they made real-life links. A student combining knowledge based on various disciplines stated this:

Teacher, it happens indirectly. If there is no water, there won't be anything in the field both we lose our food and our money decreases as the cost of living increases (Observation, April 3, 2014).

Another student gave an example of linking course content with real-life as expressed in this comment:

As a result of an incident we live, we learn that a product or food is bad after that we cannot seek our right because of various reasons they do not care that food or ... therefore these kinds of things consumer associations help us and they help us seek for our rights (Observation, April 10, 2014). 


\subsection{Students' Views Regarding the Implementation Process}

Categories emerging from the data obtained from interviews and evaluation forms were, the structure of the implementation process, contribution of this process to students learning, the difficulties they faced with during this process and suggestions regarding enhancing the process. These categories and sub-categories from students' views are shown in Figure 3.

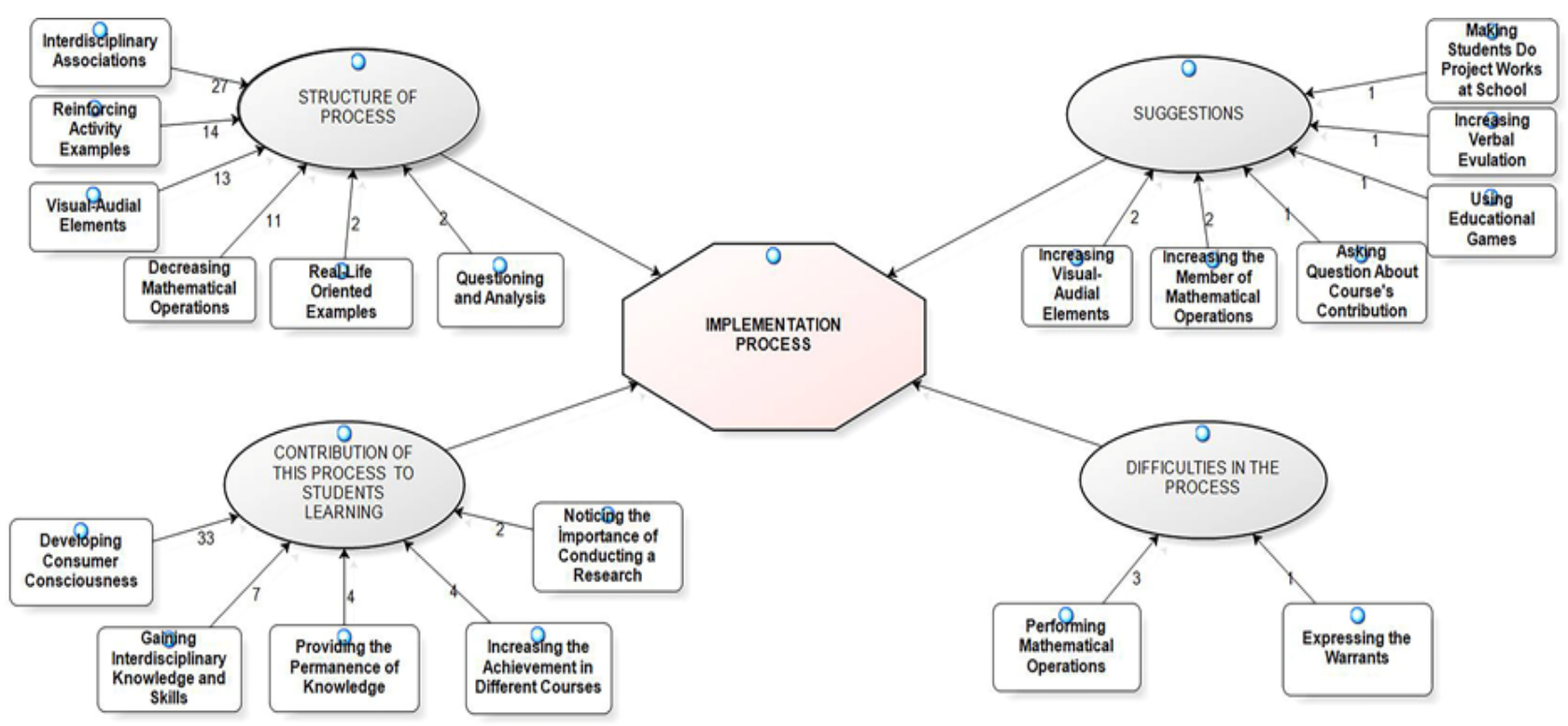

Figure 3. Students' views regarding the implementation process

Analyzing Figure 3, we found that students addressed a learning-teaching process making interdisciplinary associations, including reinforcing activity samples, visual-audial elements, questioning and analysis and through which mathematical operations decreased. One of the participants expressed the interdisciplinary links as:

Every course was included not based on only one. Many based on one topic Media literacy, Visual, Mathematics, Social sciences, Science we did everyone I mean... there something about discounts... there were about colors. The most enjoyable was that.... Media literacy, Visual, Science even just a little, Science was taken as a basis for global warming. Social sciences were dominant and there was also Maths (S7, p. 2).

The view of a student mentioning the decrease of mathematical operations was:

We don't do the things we do mostly through selective courses in Maths. Maths is full of operations but this is like social sciences.... More enjoyable than Maths (S2, Evaluation Form, March 20, 2014).

Students mentioned that learning-teaching process contributed to the development of consumer consciousness, gaining interdisciplinary knowledge and skills, providing the permanence of knowledge, increasing the achievement in different courses and raising their awareness around the importance of conducting research. Students stated the development of consumer consciousness through the course design in this way:

For instance, I did not know some rights. Now you taught and I knew. I learned how I won't waste anything.... We did not speak about conscious consumer in Social sciences course but in this course, we talk a lot, get in details. What we will do what we won't do for example... (S1, p. 3).

I understood the meaning of colors and that some posters are trickery (Student AÇ, Evaluation form, May 15, 2014).

Not to make the mistakes we should not make through examples of our life. It provided us overcome the problems we can encounter during shopping. We became more conscious about the incidents (ST, Evaluation form, May 22, 2014).

Another student emphasized the gaining of interdisciplinary knowledge and skills: 
Social sciences and Mathematics... For example, teacher sometimes we the old pieces in social sciences for example famous places in Adana Central Mosque, Maiden's Castle in Mersin and so in Social sciences courses these we deal with, that's it. In maths, teacher, for instance I did calculations teacher travel fee, I did these operations (S5, $\mathrm{pp}$. 5-6).

Students had difficulties in performing mathematical operations and expressing the warrants. S3 stated having difficulties in mathematical operations:

I had difficulty in percentages part... there was written 150. Five percent and ten percent plus $150 \ldots .$. I had difficulty there. I had difficulty in making calculations (S3, p. 3).

On the other hand, under the recommendations regarding enhancing the process category students mentioned the increase of mathematical operations and visual-audial elements, asking questions regarding course's contributions, using educational games, increase of verbal evaluation and making students work on project assignments in schools. This student recommended increasing the mathematical operations:

Teacher a little more math topics, problem, question with marks...Something about fractions... (S6, p. 6).

Another student indicated that visual-audial elements should be increased and project assignments should be carried out in schools:

... In any case, as they do not like writing you can make the topic more enjoyable with a short summary, series or films. Or you can make it as question and answer. Besides, you give those project assignments, I think you should make them bring and make them in class during the time you will teach the lesson. They are not done at home, nobody cares for them, as teacher does not give grades for them. This could also provide it to be more enjoyable. These I mean could be done at school (S7, pp. 6-7).

\section{Discussion}

This study was aimed to implement and evaluate the instructional design called "Conscious Consumer Education" centering on the concept of consumption and based on interdisciplinary approach. Findings of the study showed that implementer-researcher presented and made the knowledge sensible, strengthened interdisciplinary associations supported higher order thinking and guided the process. It was put forward that students made interdisciplinary links and used their thinking skills throughout the process. We found similarities between the findings of the study and the literature about features of interdisciplinary implementations (Doğan, 2014; Meeth, 1978 cited in Garkovich, 1982; Jacobs, 1989; Erickson, 1995; Y1ldırım, 1996; Martinello, 2000; Özkök, 2005; Mansilla \& Duraisingh, 2007; Campbell \& Henning, 2010). In this sense, it could be said that the features indicated through related literature are frequently observed.

Furthermore, when the findings were analyzed in detail, it was observed that there were performance indicators regarding thinking skills but the increase in the level of these skills were not as expected. In particular analysis skills were observed at mostly comprehension level while the frequency of the other categories was also low. This situation could be linked to a lack of prior knowledge regarding various fields fundamental for thinking processes. Since, thinking being a content dimension consisting of knowledge (Sigel,1991), in terms of using thinking processes the individual should connect new knowledge s/he obtained with his/her prior knowledge and experiences (Paul, 1991; Doğanay, 2009; Glaser 1941 cited in Alazzi, 2008). That the inefficiency of readiness level and motivation of students and the deficiencies through their previous learning making the teaching process difficult was put forward in Barnes' (2011) study shows parallels with the findings of the study. Also, that the need for supplementing prior knowledge of students came out in the study conducted by Wagner et al. (2012) is an indicator of students' prior knowledge and skills' being among the factors leading an interdisciplinary course design.

The students' indicating that they had difficulties in performing mathematical operations and expressing warrants also supports this argument. Another reason for this was insufficiency of the time necessary for both increasing the students' prior knowledge and skills and providing the development of their thinking skills. The mathematics practices course, in which this study was conducted, was only two hours a week. This was considered was a factor preventing the holistic development and this situation created a difficulty in developing higher order thinking skills making interdisciplinary links. That the teaching time's insufficiency making the learning process harder was put forward through also studies about interdisciplinary implementations supports this opinion (Brown, 2012; Herrera, 2013).

As for student views regarding implementation process, participants stated that this process contributed to their development of consumer consciousness, gaining interdisciplinary knowledge and skills, providing the permanence of knowledge, increasing the success in various courses and noticing the importance of conducting a 
research. This situation indicated that the instructional design putting consumption concept into the center was also effective in students' gaining conscious consumer behaviors. That the implementations based on interdisciplinary approach contributed to students' reaching learning outcomes and ensuring permanent learning was also found in Doğan's (2014) study.

Consequently, according to this study, it was indicated that instructional design which was developed with an interdisciplinary approach contributed to gain interdisciplinary knowledge and skills and develop consumer consciousness. In the light of these results we may conclude that this design is implementable. However, it was clear that the students had difficulties in points such as performing mathematical operations and expressing warrants. These situations made the implementation process more difficult.

With the obtained results, it is expected that different approaches taken as a basis in mathematics education should be developed to contribute to the implementations regarding maths' use in real life. Another result of the study is to increase the achievement in interdisciplinary implementations that there is a need for studies regarding the development of prior knowledge and skills of different disciplines and it is necessary to make effective regulations for cooperation of teachers from different disciplines.

The interdisciplinary course design also highlights the necessary competencies of the teacher across various disciplines. Hence, it is necessary to develop knowledge and skills of teachers and pre-service teachers regarding this approach through both pre-service and in-service trainings. The implementation of instructional design was carried out at six grade level. With the aim of observing the implementation of interdisciplinary approach at different grade levels similar studies at other grade levels should be conducted.

\section{Acknowledgments}

This study was supported by Çukurova University Scientific Research Projects with grant number of EF2013BAP13.

\section{Note}

This study was presented at International Congress on Education for Future: Issues and Challenges (ICEFIC) (May 13-15, 2015, Ankara, Turkey).

\section{References}

Alazzi, K. (2008). Teachers' perceptions of critical thinking: A study of Jordanian secondary school social studies teachers. The Social Studies, 99(6), 243-248. http://dx.doi.org/10.3200/TSSS.99.6.243-248.

Altıok, N., \& Babaoğul, M. (2010). Türkiye'de ve AB ülkelerinde tüketici eğitimi. In M. Babaoğul \& A. Şener (Eds.), Tüketici yazıları II [Consumer writings II] (pp. 23-46). Ankara: Hacettepe University.

Armstrong, T. (2000). Multiple intellegences in the classroom. VA, USA: Association for Supervision \& Curriculum Development.

Babaoğul, M., \& Altıok, N. (2007). Evrensel tüketici hakları. In M. Babaoğul \& A. Şener (Eds.), Tüketici yazllarl I [Consumer writings I] (pp. 27-42). Ankara: Hacettepe University.

Barnes, T. (2011). Making the grade: a qualitative case study of curriculum integration among students participating in a community college construction technology program (Unpublished doctoral dissertation). University of Wyoming, USA.

Bazemore, C. (2015). Teachers' perceptions of an integrated third grade curriculum's effects on students' reading achievement (Unpublished doctoral dissertation). Walden University, USA.

Bener, Ö. \& Babaoğul, M. (2008). Consumer education as a tool in forming sustainable consumer behavior and environmental consciousness. Hacettepe Üniversitesi Sosyolojik Araştırmalar e- Dergisi, 5(1), 1-10.

Bogdan, R. C., \& Biklen, S. K. (2007). Qualitative research for education (5th ed.). Boston: Allyn and Bacon.

Brantlinger, E., Jimenez, R., Klingner, J., Pugach, M., \& Richardson, V. (2005). Qualitative studies in special education. Exceptional Children, 71(2), 195-207.

Bristow, A. L. (2012). An analysis of the impact of implementing interdisciplinary pods on student achievement in Georgia middle schools (Unpublished doctoral dissertation). University of Southern Mississippi, USA.

Brown, K. (2006). New educational injustices in the "new" South Africa: A call for justice in the form of vertical $\begin{array}{llll}\text { equity. Journal of Educational } & \text { Administration, 44(5), }\end{array}$ https://doi.org/10.1108/09578230610683787. 
Brown, L. (2012). Successful strategies for implementation of a high school standards-based integrated mathematics curriculum (Unpublished doctoral dissertation). Walden University, USA.

Büyükkantarcıoğlu, N. (2007). Reklam söyleminde yanıltıcı argümanlar ve tüketici farkındalığı. In M. Babaoğul \& A. Şener (Eds.), Tüketici yazılarl I [Consumer writings I] (pp. 97-14). Ankara: Hacettepe University.

Campbell, C., \& Henning, M. B. (2010). Planning, teaching and assessing elementary education interdisciplinary curriculum. International Journal of Teaching and Learning in Higher Education, 22(2), 179-186.

Caplinger, R. T. (2013). The impact of flexible interdisciplinary block scheduling on reading achievement (Unpublished doctoral dissertation). University of Oregon, USA.

Çınar, R., \& Çubukçu, İ. (2009). Formation of consumption society and consumer behavior -a comparative application. Atatürk University Journal of Graduate School of Social Sciences, 13(1), 277-300.

Creswell, J. W. (2008). Educational research: planning, conducting and evaluating quantative and qualitative research (3rd edition). Upper Saddle River, NJ: Pearson Education, Inc.

Dean, D. (2014). Comparing standardized test scores among arts-integrated and non-arts integrated schools in central Mississippi (Unpublished doctoral dissertation). University of Phoenix, USA.

Doğan, C. (2014). Assessing the impact of the lesson process interdisciplinary teaching success of geography (Unpublished master's thesis). Gazi University, Turkey.

Doğanay, A. (2009). Üst düzey düşünme becerilerinin öğretimi. In A. Doğanay (Ed.), Öğretim ilke ve yöntemleri [Teaching principles and methods] (pp. 304-352). Ankara: Pegema Yayıncilık.

Drake, S. M. (2007). Creating standards-based integrated curriculum: Aligning curriculum, content, assessment, and instruction. Thousand Oaks, CA: Corwin Press Corwin Press.

Erickson, H. L. (1995). Stirring the head, heart, and soul: Redefining curriculum and instruction. California: Corwin Press.

Faulkner, S. F. (2012). Science literacy: Exploring middle-level science curriculum structure and student achievement (Unpublished doctoral dissertation). University of Hartford, USA.

Garkovich, L. (1982). A proposal for building interdisciplinary bridges. Teaching Sociology, 9(2), 151-168.

Giglio, L. E. (2012). Imagication = imagination + education: what fifth graders think about arts integration in public elementary schools (Unpublished doctoral dissertation). University of San Francisco, USA.

Guba, E. G. (1981). Criteria for assessing the trustworthiness of naturalistic inquiries. ERIC/ECTJ Annual Review Paper, 29(2), 75-91.

Guthrie, J. T., Wigfield, A., \& VonSecker, C. (2000). Effects of integrated instruction on motivation and strategy use in reading. Journal of Educational Psychology, 92(2), 331-341. http://dx.doi.org/10.1037//9022-0663.92.2,331.

Güzeloğlu, C. (2010). Ambalaj tasarımında görsel bir unsur olarak rengin, tüketici algısı üzerindeki rolü. In M. Babaoğul \& A. Şener (Eds.), Tüketici yazıları II [Consumer writings II] (pp. 271-292). Ankara: Hacettepe University.

Hayta, A. B. (2009). The role of consumer education in achieving sustainable consumption behavior. Ahi Evran University Journal of Kırşehir Education Faculty, 10(3), 143-151.

Hekimci, F. (2010). Ekonominin yükselen değerleri, "etik tüketicilik" ve "etik ticaret". In M. Babaoğul \& A. Şener (Eds.), Tüketici yazıları II [Consumer writings II] (pp. 47-65). Ankara: Hacettepe University.

Herrera, K. L. (2013). Evaluating the effect of an online job-embedded professional development program on elementary teachers' use of arts integrated approaches to learning in a South Texas school district (Unpublished doctoral dissertation). Texas A\&M University, USA.

Jacobs, H. H. (1989). Interdisciplinary curriculum: Design and implementation. Association for Supervision and Curriculum Development.

Johnson, B., \& Christensen, L. (2004). Educational research: quantitative, qualitative and mixed approaches (2nd ed.). Boston: Pearson Education Inc.

Jones, C. (2010). Interdisciplinary approach-advantages, disadvantages, and the future benefits of interdisciplinary studies. ESSAI, 7(1), 76-81. 
Joseph, A. (2013). The effects of creative dramatics on vocabulary achievement of fourth grade students in a language arts classroom: An empirical study (Unpublished doctoral dissertation). Seattle Pacific University, USA.

Kander, R. G. (2003). A successful experiment in curriculum integration: Integrated science and technology at James Madison University. Proceedings of the 33rd ASEE/IEEE Frontiers in Education Conference. Colorado, Champaign: Stipes Publishing.

Karakuş, M., \& Yeşilpınar, M. (2013). An example of practice based on interdisciplinary approach: Conscious consumer instruction. In J. C. Morgado, M. P. Alves, I. Viana, C. Ferreira, F. Seabra, N. V. Hattum-Janssen \& J. A. Pacheco (Eds.), Proceedings of the European Conference on Curriculum Studies. Future Directions: Uncertainty and Possibility (pp. 854-861). Braga, Portuguese.

Kelly, M. (2011). A participatory action research study of arts integration in transitional studies-English at the art institute of California-San Francisco (Unpublished doctoral dissertation). Argosy University, USA.

Loepp, F. L. (1999). Models of curriculum integration. Retrieved from http://scholar.lib.vt.edu/ejournals/JOTS/Summer-Fall-1999/Loepp.html.

Lomofsky, L., \& Lazarus, S. (2001). South Africa: First steps in the development of an inclusive education system. Cambridge Journal of Education, 31(3), 303-317. http://dx.doi.org/10.1080/03057640120086585.

Lonning, R. A., DeFranco, T. C., \& Weinland, T. P. (1998). Development of theme - based, interdisciplinary, integrated curriculum: A theoretical model. School Science and Mathematics, 98(6), 312-319. http://dx.doi.org/10.1111/j.1949-8594.1998.tb17426.x.

Lynch, K. (2013). Music as a useful strategy for teaching academics in elementary school education (Unpublished doctoral dissertation). Cambridge College, USA.

MacMath, S. L. (2011). Teaching and learning in an integrated curriculum setting: a case study of classroom practices (Unpublished doctoral dissertation). University of Toronto, Canada.

Mallanda, C. L. (2011). The effects of changing from a traditional mathematics curriculum to an integrated mathematics curriculum on student mathematics learning in Georgia (Unpublished doctoral dissertation). University of Southern Mississippi, USA.

Mansilla, V. B., \& Duraisingh, E. D. (2007). Targeted assessment of students' interdisciplinary work: An empirically grounded framework proposed. The Journal of Higher Education, 78(2), 215-237.

Martin, A. R. (2011). Curriculum integration, learner-centered, and curriculum-centered approaches in a high school mathematics course (Unpublished doctoral dissertation). University of Houston-Clear Lake, USA.

Martinello, M. L. (2000). Interdisciplinary inquiry in teaching and learning. Upper Saddle River: Gillian E. Cook.

Merriam, S. B. (1998). Qualitative research and case study applications in Education. Revised and expanded from case study research in education. San Francisco: Jossey-Bass Publishers.

Miller, M. (2011). Integration of an arts-based curriculum in a K-5 charter school (Unpublished doctoral dissertation). Walden University, USA.

Nickson, G. D. (2014). Impact of middle school student participation in the whole schools' initiative arts program (Unpublished doctoral dissertation). Mississippi State University, USA.

Öktem, M. \& Seçkiner, E. (2010). Bilgi toplumu ve kamu yönetimi bağlamında bireyin yeri: Vatandaş mı tüketici mi? In M. Babaoğul \& A. Şener (Eds.), Tüketici yazıları II [Consumer writings II] (pp. 23-45). Ankara: Hacettepe University.

Özkök, A. (2005). Effects of interdisciplinary creative problem solving teaching program on creative problem solving skills. Hacettepe University Journal of Education, 28, 159-167.

Patton, M. Q. (2002). Qualitative evaluation and research methods (3rd ed.). London: Sage Publications.

Paul, R. W. (1991). Teaching critical thinking in the strong sense. In A. Costa (Ed.), Developing minds (pp. 77-84). Alexandria: Virginia. ASCD.

Pektaş, Ö. (2007). Tüketicinin korunması açısından reklam kurulu çalışmaları. In M. Babaoğul \& A. Şener (eds). Tüketici yazllarl I [Consumer writings I] (pp. 89-96). Ankara: Hacettepe University. 
Peterson, J. A. (2012). A quantitative study comparing the academic achievement of seventh grade reading students exposed to two types of reading strategies (Unpublished doctoral dissertation). Capella University, USA.

Pierce, K. B. (2013). Do mathematics and reading competencies integrated into career and technical education courses improve high school student state assessment scores? (Unpublished doctoral dissertation). University of South Florida, USA.

Şener, A. (2010). Medya, reklam ve tüketim: Çocuklar açısından bir değerlendirme. In M. Babaoğul \& A. Şener (Eds.), Tüketici yazlları [Consumer writings II] (pp. 153-177). Ankara: Hacettepe University.

Shenton, A. K. (2004). Strategies for ensuring trustworthiness in qualitative research projects. Education for Information, 22, 63-75.

Stake, R. E. (1995). The art of case study research. Thousand Oaks, California: Sage Publications.

Tanriverdi, B. (2009). Analyzing primary school curriculum in terms of sustainable environmental education. Education and Science, 34(151), 89-103.

Thompson, J. C. (2015). The student experience of arts integration: A phenomenological investigation (Unpublished doctoral dissertation). Morgan State University, USA.

Tuncel, Z. A., \& Demirel, M. (2010). Effects of an integrated curriculum implementation on the cooperative skills of 4th grade elementary education students. Ballkesir University Journal of Social Sciences Institute, 12(22), 111-128.

Ulusoy, G. (2007). Disiplinlerarası araştırma ve eğitim. In C. C. Aktan (Ed.), Değişim çağında yükseköğretim: Global trendle-paradigmal yönelimler [Higher education in era of change: Global trends- paradigmatic tendencies]. İzmir: Yaşar University.

Ürey, M. (2013). Development and evaluation of science-based and interdisciplinary school garden program within the scope of free activity studies course (Unpublished doctoral dissertation). Karadeniz Teknik University, Turkey.

Wagner, H. H., Murphy, M. A., Holderegger, R., \& Waits, L. (2012). Developing an interdisciplinary, distributed graduate course for twenty-first century scientists. BioScience, 6(2), 182-188. https://doi.org/10.1525/bio.2012.62.2.11.

Wei, K. M. (2012). Discovering learning, discovering self: the effects of an interdisciplinary, standards-based school garden curriculum on elementary students in Hawai'i (Unpublished doctoral dissertation). Prescott College, USA.

Yıldırım, A. (1996). Disiplinler arası öğretim kavramı ve programlar açısından doğurduğu sonuçlar [Interdisciplinary instruction concept and its results regarding curricula]. Hacettepe University Journal of Education, 12, 89-94.

Yıldırım, A., \& Şimşek, H. (2008). Sosyal bilimlerde nitel araştırma yöntemleri [Qualitative research methods in social sciences] (7th ed.). Ankara: Seçkin Yayıncılık.

Yıldız, D. G., \& Bümen, N. T. (2013). Effects of cooperative learning and conflict resolution training integrated into curriculum on academic achievement, social problem solving skill. Turkish Journal of Education, 2(4), $28-43$.

Yin, R. K. (2003). Case study research: Design and methods (3rd ed.). Beverly Hills, CA: Sage Publications.

\section{Copyrights}

Copyright for this article is retained by the author(s), with first publication rights granted to the journal.

This is an open-access article distributed under the terms and conditions of the Creative Commons Attribution license (http://creativecommons.org/licenses/by/4.0/). 